\title{
The rocky road from insight to understanding.
}

DOI:

10.1108/MRJIAM-10-2017-0789

\section{Document Version}

Accepted author manuscript

Link to publication record in Manchester Research Explorer

\section{Citation for published version (APA):}

Walsh, J., White, J., \& Edwards, J. (2018). The rocky road from insight to understanding. Management Research: Journal of the Iberoamerican Academy of Management. https://doi.org/10.1108/MRJIAM-10-2017-0789

\section{Published in:}

Management Research: Journal of the Iberoamerican Academy of Management.

\section{Citing this paper}

Please note that where the full-text provided on Manchester Research Explorer is the Author Accepted Manuscript or Proof version this may differ from the final Published version. If citing, it is advised that you check and use the publisher's definitive version.

\section{General rights}

Copyright and moral rights for the publications made accessible in the Research Explorer are retained by the authors and/or other copyright owners and it is a condition of accessing publications that users recognise and abide by the legal requirements associated with these rights.

\section{Takedown policy}

If you believe that this document breaches copyright please refer to the University of Manchester's Takedown Procedures [http://man.ac.uk/04Y6Bo] or contact uml.scholarlycommunications@manchester.ac.uk providing relevant details, so we can investigate your claim.

\section{OPEN ACCESS}


The Rocky Road from Insight to Understanding

\author{
James P. Walsh \\ Ross School of Business \\ University of Michigan \\ B. Joseph White \\ College of Business \\ University of Illinois at Urbana-Champaign \\ Jeffrey R. Edwards \\ Kenan-Flagler Business School \\ University of North Carolina
}

Google Scholar tells us that there are 254,000 papers and books on the topic of CEO compensation and firm performance. Picking up the Aguinis, Martin, Gomez-Mejia, O'Boyle and Joo (2017) manuscript, we had to ask, "Do we really need to read this paper?" As always, the answer to that question hinges on whether or not we learn anything new from the work. Pointing out that the distribution of CEO compensation is skewed, Aguinis et al. (2017) ask us to account statistically for the fact that a power-law distribution may better capture the phenomenon than a normal distribution. In the end, they suggest that our understanding of CEO compensation may be mistaken.

With the results of perhaps a quarter of a million studies called into question, that is a very compelling hook for a paper. They certainly captured our attention. Discovering no empirical relationship between CEO pay and performance, Aguinis et al. (2017) flagged the groups of high performance / low pay and high pay / low performance CEOs to argue that we need to learn much more about CEO underpayment and overpayment. Despite all of the past work in this area, they conclude that flawed analytic reasoning leaves us with a poor understanding of CEO compensation.

Drawn to their insight, we read their work very carefully. We must confess that we set the paper down concerned about many aspects of their empirical effort. Unfortunately, we cannot accept the results of their investigation as they stand now. As a result, we cannot say anything about how their findings complement or challenge our extant understanding of CEO compensation. Pointing to our concerns about their empirical work, we will do our best to offer an improved analytic path forward. To be sure, we take no joy in criticism. We are simply trying to help as best we can. The road from insight to understanding is rarely smooth.

\title{
Their hook
}

"Past empirical work on the relation between CEO performance and CEO pay has relied on the assumption that performance is normally distributed or can be readily transformed to normality with little to no loss of data integrity" (p. 10).

"By using a power law conceptualization of the CEO pay distribution, we are able to examine differences in pay across CEOs as they actually exist" (p. 5). 
Reading about CEOs' mega compensation packages (Goldstein, 2017), a claim that the distribution of CEO pay in our publicly traded corporations is something other than normal is valid on its face. Beyond that, the routine use of Winsorization and log transformations in our research says as much. The authors grabbed our attention right away: "The shape of the distribution is not just a methodological curiosity. Rather, it has profound implications for theory because it changes how we conceptualize the nature of constructs such as CEO performance and CEO pay" (p. 10). To be sure, we are very curious to learn if our understanding of pay and performance changes if we account for skewed distributions in our models.

\section{Their results}

\section{Paying for performance}

"Our results show that CEOs at the top of the performance distribution create vastly more value than those at succeedingly lower levels of the performance distribution, and those CEOs at the top of the pay distribution are remunerated far more than those at succeedingly lower levels of the pay distribution. But, there is little overlap between CEOs who are the top performers and CEOs who are the top earners" (p. 33).

The authors begin the review of their pay and performance results by noting "a large degree of mismatch between CEO performance and pay" (p. 22). Observing that only 5 percent (and 4 percent) of the CEOs in this sample reside in both the top 1 percent of both the pay and Tobin's Q (ROA) performance distribution, they conclude, "the overlap of the highest performers with the highest earners in terms of total pay is very low" (p. 26). Even more strikingly, looking at their results with a Kendall's $\tau$ coefficient, they observe, "there is no association between CEO performance and pay" ( $p$. 26).

In an understated fashion, they end their paper by concluding, "the observed decoupling between top CEO pay and performance seems difficult to justify based on rational economic and distributive justice grounds" (p. 29). Results in hand, they wonder how those who are paid so well for less than top performance "game the system" (p. 29) and in this light, suggest that their empirical approach will help headhunters find the top performers who are not so handsomely compensated (p. 32).

This is a striking result and one that needs a good deal more attention. To be sure, just about every compensation committee member (and their consultants) in America would take issue with it. These committees write an annual Compensation Discussion and Analysis section into their annual proxies with the explicit purpose of explaining how performance drives pay in their companies. Shareholders then usually provide overwhelmingly positive say-on-pay votes. Of course, these shareholders include deeply knowledgeable people from the big institutional investors (e.g., Vanguard, Blackrock and Fidelity) who keep electing the directors - directors whom the authors might see as dupes or worse.

The authors have an enormous obligation to provide rock solid empirical support for a conclusion like this. Many directors believe that industry has a huge effect on CEO pay. For example, directors reading this paper will immediately say that media and finance pay high and that some manufacturing and service industries pay "low." They will wonder why a look at industry does not temper their conclusions. Academics reading this paper will wonder why these results do not line up with the results of the latest meta-analysis in the area. van Essen, Otten and Carberry's (2015) analysis of 219 studies on this topic found a significant .12 relationship between pay and performance. Wondering why the authors do not replicate past work, we are interested to learn if it is because the 219 studies are flawed (their 
assumptions about a normal distribution may cripple their efforts) or if it is because the current work is flawed in some fashion. We cannot look at the 219 studies but we can take a close look at this project.

\section{Overpayment and underpayment}

The authors are interested in what happens at the tails of these pay and performance distributions. Looking at those who show up at the top of the pay distribution but live somewhere near the lower end of the performance distribution (colloquially known as members of the executive compensation "Hall of Shame"), they wonder about overpayment and how it comes to be, raising questions about the CEOs' negotiation capabilities, power, and the deft use of compensation consultants for their own benefit. Adding to their questions, we would love to know more about why and how boards permit and perpetuate the practice of overpaying for weak performance. And again, we wonder why investors in those companies often - but not always - provide favorable "say on pay" votes for these compensation arrangements. These are important questions. We are grateful to Aguinis et al. (2017) for bringing them to our attention.

Having said that, we all know that concerns about CEO overpayment are not new. Warren Buffett (2003: $18)$, for example, rang the alarm bell almost fifteen years ago:

"In recent years, compensation committees too often have been tail-wagging puppy dogs meekly following recommendations by consultants ... This costly charade should cease. ... There's nothing wrong with paying well for truly exceptional performance. But, for anything short of that, it's time for directors to shout "less!" It would be a travesty if the bloated pay of recent years became a baseline for future compensation. Compensation committees should go back to the drawing boards."

And to be sure, concerns about bloated pay still linger. For example, the New York Times reported this spring that Thomas Rutledge, Charter Communication's CEO, made \$98M in 2016, noting, "pay for top executives is reaching staggering levels" (Goldstein, 2017). More recently, the Harvard Business Review considered some remedies for excessive CEO compensation (Pozen and Kothari, 2017; Radhakrishnan, Horn and Milbourn, 2017). We welcome any investigation of CEO overpayment and ideas about what to do about it.

Contrariwise, those who show up at the top of the performance distribution but lie somewhere near the bottom of the pay distribution (unsung members of the executive compensation "Hall of Fame") also capture their imagination. Raising the specter of underpayment, they ask us to consider how that phenomenon unfolds. With so much talk of wealth inequality in the air these days (Piketty, 2014), we are intrigued with the idea of CEO underpayment. Hardoon (2017) recently made news with her observation that the richest eight men in the world hold as much wealth as the poorest half of the world. Despite gains in lifting more than 1 billion people out of abject poverty in the last 25 years (with poverty defined as living on less than $\$ 1.90 /$ person/day PPP), perhaps 700 million people still subsist on that kind of income (Cruz, Foster and Schellekens, 2015). In a world still struggling with extreme poverty and manifest income/wealth inequality, many wonder why we need to pay CEOs even more money to do their jobs.

The AFL-CIO's Executive Paywatch (2017) reports that the average S\&P 500 CEO received \$13.1M in total compensation in 2016, a year when the average "production and nonsupervisory employees earned $\$ 37,632$." Concerns about inequality call the question of just what constitutes underpayment. 
Here, the authors view underpayment through a pay-for-performance lens. Of course, decisions about the magnitude of pay say nothing about the relationship between pay and performance. A pay-forperformance relationship can hold with a mean income of $\$ 37 \mathrm{~K}$ just as it can with an average income of $\$ 13 \mathrm{M}$. The amount of compensation that a board grants its CEO speaks to a dynamic other than just a relationship between that pay and performance. Tournament models of compensation (Lazear and Rosen, 1981), for example, speak to settings where people prefer pay to be paid on rank, not performance. Rosen (1986) pointed out that competitive tournaments may need a very large final prize (think "excessive CEO compensation") to maintain everyone's performance throughout the game.

Foreshadowing a conversation about a skewed distribution, Fox News' Perry Chiaramonte (2017) immediately moved to put the Executive Paywatch (2017) report in context. In protest, he pointed out that the Bureau of Labor Statistics has data on 246,240 "chief executives" and noted that these people earned an average of $\$ 180,700$ in $2014 \ldots$ and that Richard Trumka, the AFL-CIO's president, earned $\$ 294,537$ that same year. Dun and Bradstreet (2017) have data on 280 million commercial entities around the world. Are we interested in the compensation of the S\&P 500's chief executives, the quarter of a million individuals in the US who lead their commercial entities, or the $\mathbf{2 8 0}$ million people around the world who do this kind of work? Given that a concern about an owner - manager agency conflict (Jensen and Meckling, 1976) fuels so much interest in CEO compensation, we believe that scholars are most interested in the compensation arrangements for those who lead publicly traded companies. To that point, the World Bank (2017) identified 43,182 publicly traded companies in the world. Perhaps we are most interested in the publicly traded companies - or the subset of such companies in the US. Still, the selective use of statistics tells us that the issue is as complicated as it is fraught. ${ }^{1}$ We have to get our statistics right.

Provocative research results always draw a second look. Taking stock of the project's details, we came away wondering about many of the authors' research decisions. We believe that future researchers should better collect and analyze the kinds of data we see here. Again, sadly, we do not recommend that anyone accept the current results at face value.

\section{Their Research Decisions}

Before we say another word, we should point out that this kind of invited commentary defines a healthy scholarly community. We admire Herman Aguinis and his colleagues for their creativity and prodigious effort here... and for their invitation, and even courageous invitation, to have folks like us comment on their work. Giving us all a chance to learn some vicarious lessons about research design and execution from them, we hope that our readers will appreciate the complex challenges they faced. We also hope that these same readers will be willing to roll up their sleeves and help with the follow-up work we need here. All of that said, let's take a look at their sampling, measurement, and analytic decisions.

\section{Sampling}

\footnotetext{
${ }^{1}$ While Chiaramonte (2017) was clearly working to deflate our understanding of the earning of CEOs (from $\$ 13.1 \mathrm{M} /$ year to $180 \mathrm{~K}$ /year!), the AFL-CIO was also trying to deflate our understanding of workers' earnings. Their difference is nowhere nearly as dramatic as what Fox News reported but we should point out that the Bureau of Labor Statistics (2017) reports that the median weekly income for the 11.3 million full-time wage and salary workers in the US (for the $4^{\text {th }}$ quarter of 2016) was $\$ 849$ (\$758 for women and $\$ 927$ for men). That works out to $\$ 44,148 /$ year, not the more circumscribed $\$ 37,632$ figure that the AFL$\mathrm{CIO}$ reported. Statistics provide the ammunition used on the front lines of the culture wars.
} 
As Table 1 illustrates, their 1992-2012 sampling window captured a volatile period in US history, one marked by financial booms and busts. We may not want to treat any period of CEO tenure in this 20year time period as the same as any other. Looking at month-end data, we see that the market grew by more than 350 percent between January $1992(3,223)$ and December $1999(11,497)$; it then lost about one third of its value in the next 33 months $(7,592)$. The market then almost doubled in the ensuing five years, closing at 13,896 on December 30, 2007. The Great Recession then hit us hard, with the market losing about half of its value in the next 18 months (closing at 7,073 on February 28, 2009). Since then, the market has been on an extraordinary run - closing at 13,104 at the end of their sample period and 22,405 on September 28,2017 . It would be good to see if the pay for performance relationships in periods of strong growth are the same as they are in periods of decline.

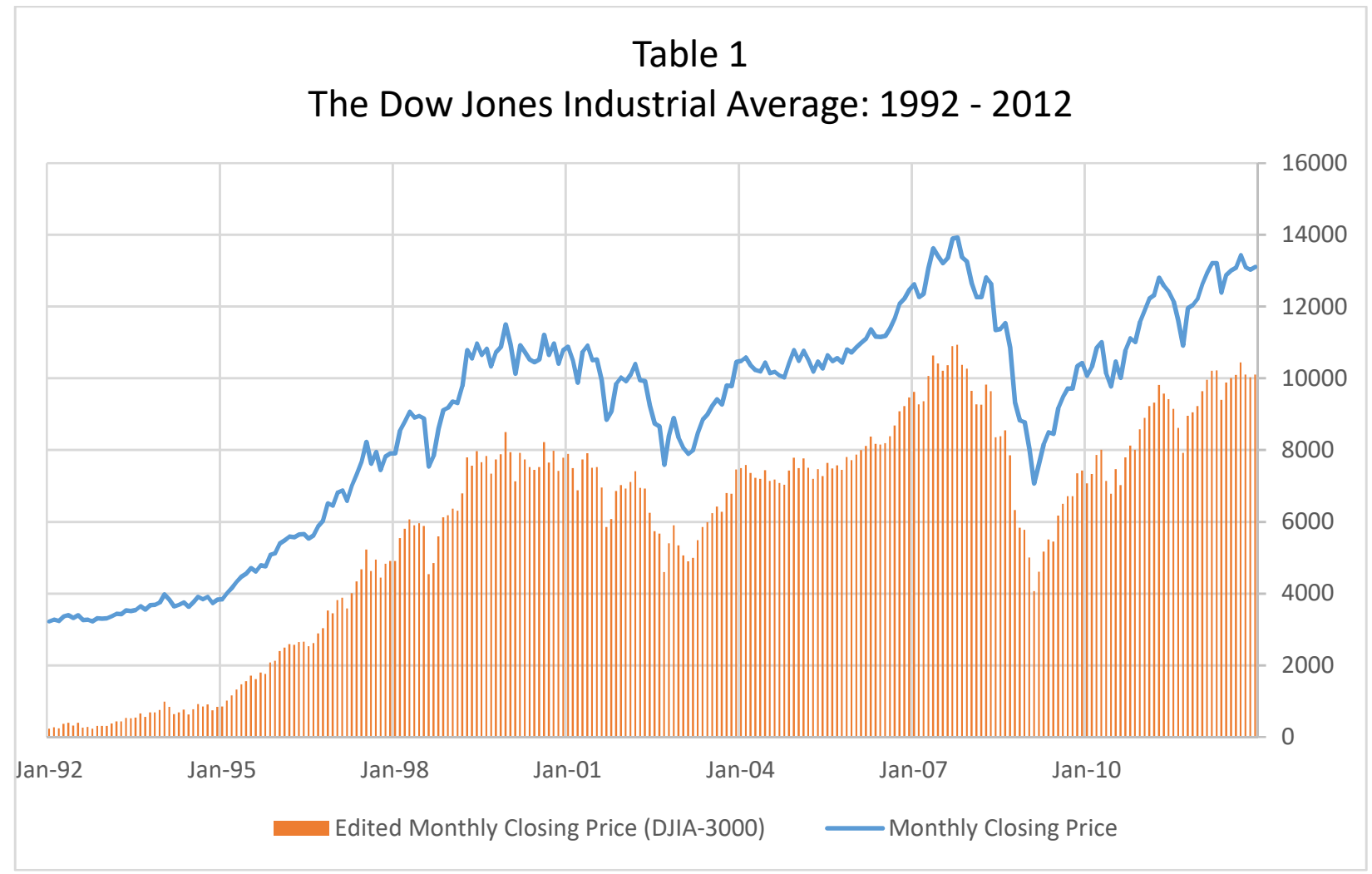

How did the authors handle left and right censoring as they collected their CEO data? They stated, "We examined firm performance and CEO pay during the tenure of each separate CEO and excluded the first year of each CEO's tenure" (p. 14). Some of the CEOs available to them began their time in office before the observation window opened in 1992 and finished their service before 2012; others began their careers before 2012 but finished their service after the observation window closed. The authors do not talk about how they handled this censoring issue as they described their data. It would be good to tell the reader if -- and how many of-- the CEOs whose tenures were left-censored and right-censored were in fact excluded from the analyses, and then how many complete CEO tenure profiles they have in their sample. Of course, it would also be nice to know the mean, standard deviation and range of those tenures profiles. We know that they controlled for the length of the CEO's service (p.15) but we do not know how long that service was and what that distribution of service looks like. 
The World Bank (2017) tells us that we have seen a significant shift in the number of publicly traded companies in this time period. The number of US public companies peaked in 1996 (at 8,090). It has declined ever since. Sampling from the $1992-2012$ time period, their data capture changing labor market conditions. The overall 36 percent drop in the number of companies in their sampling window masks some change. While starting with 6,446 companies in 1992 and ending with 4,102 in 2012, we do see, however, a 26 percent increase in the number of public companies between 1992 and 1996 ... and then a 49 percent decline in the following 16 years. Since pay can respond to labor market dynamics of supply and demand, it would be good to control for such change as we examine CEO compensation.

\section{Table 2}

\section{Number of US Public Companies}

$\begin{array}{cccc}\text { Year } & \text { Number } & \text { Year } & \text { Number } \\ 1992 & 6,446 & 2003 & 5,295 \\ 1993 & 6,912 & 2004 & 5,226 \\ 1994 & 7,255 & 2005 & 5,145 \\ 1995 & 7,487 & 2006 & 5,133 \\ 1996 & 8,090 & 2007 & 5,109 \\ 1997 & 7,905 & 2008 & 4,666 \\ 1998 & 7,499 & 2009 & 4,401 \\ 1999 & 7,229 & 2010 & 4,279 \\ 2000 & 6,917 & 2011 & 4,171 \\ 2001 & 6,177 & 2012 & 4,102 \\ 2002 & 5,685 & & \end{array}$

And then of course, we need to consider the usual question of sampling bias. Examining data that are available in Execucomp and Compustat, they examined 4,158 and 5,091 annual CEO-firm combinations, net of the CEOs' first year on the job. That is an impressively large sample. However, sum the number of public companies in the US between 1992 and 2012, and we discover that there were 125,129 possible CEO-firm combinations to explore. Holding aside questions about how many left and right censored CEOs there are in this period, and how much "first year on the job" data we would need to exclude to match their sampling strategy, it is clear that theirs is a sample drawn from a larger population of firms. Taking nothing away from the data they do have, one wonders if the observed CEOs and their companies differ in any way from the unobserved CEOs and their companies.

Finally, the Financial Accounting Standards Board (2004) changed the accounting rules to expense options in December 2004. That is a big change in the middle of their observation window, one that resulted in many boards changing the equity compensation balance from (far more) options to restricted stock. Again, it is important to keep an eye on that change as they analyze compensation setting practices in this unique time in US economic history.

\section{From constructs to variables}

There is an art and science to bringing constructs to life. Let's see how they assessed their independent, dependent, and control variables. To begin, we should recognize that we are looking at a phenomenon that unfolds year by year, accumulating over the period of a CEO's tenure. And in that light, we should 
appreciate the fact that pay in a pay-for-performance relationship can be seen as either a reward (looking at the effects of past performance on future compensation) or an incentive (looking at the effects of a compensation package on future performance). The board decides upon a compensation package every year, with an appraisal of the previous year's (or multiple years') performance in hand and an expectation for the following year's (or years') performance in mind. As such, we can see two different analyses of CEO performance:

- Pay as reward: Pay $=f$ (past performance at time $T, T-1, T-2, \ldots)$

- Pay as incentive: Pay $=f$ (expected performance at time $T, T+1, T+2, \ldots$ )

In all, looking at pay across a CEO's tenure is novel and important. It allows us to look at pay's incentive and reward effects. To be sure, both the board and the CEO are aware of the annual pay and performance results as they unfold and accumulate over the years.

The authors' measurement decisions are worth a conversation, however. The authors are most interested in how the board makes its annual compensation decisions. As such, we might expect them to look at every year of the CEO's tenure to see how the annual pay-and-performance relationship evolves in an incentive and reward fashion throughout his or her tenure. With these kinds of expectations in most readers' minds, it would be good for them to talk about the different analytical options available to them and in that light, say why they choose to examine the relationships they do (perhaps examining other choices in footnotes as robustness checks). All of that said, let's look at how Aguinis et al. (2017) assessed pay and performance. Their decisions raise some questions...and opportunities for further research.

CEO Compensation. The authors summed a CEO's total compensation throughout his or her tenure and divided that number by years of service to compute an average annual compensation measure for use in their analyses. That said, boards want pay to flex with performance. Averaging pay over a multi-year period obscures exactly the phenomenon they are seeking to understand. Frankly, we are not sure what construct their compensation variable assesses. To be sure, it is a measure of pay but it is not a measure of pay that the board sees when it makes its compensation decisions. We expected to see Aguinis et al. (2017) measure each CEOs' annual compensation and relate that figure to measures of performance in theoretically designated performance windows. We do not understand why they chose another empirical path.

Granted options vs. exercised options. Moreover, we do not understand why the authors focused on exercised options. We think that is a mistake. A study of CEO pay-for-performance is typically a study of contracting, examining how a board writes contracts that presumably align the CEO's interests with the owners' interests. Giving the CEO stock options, the board is very interested to learn whether or not the money is well spent. A look at the pay-for-performance relationship answers that question.

A study of exercised options is a study of how CEOs work to ensure their own interest. That is why CEO stock sales are a hallmark of insider trading studies (Ke, Huddart and Petroni, 2003) or selfdealing more broadly. Brockman, Martin and Puckett (2010), for example, examined how CEOs might strategically exercise their options around the release of bad news. Since the authors are interested in how boards design compensation contracts to ensure firm performance, they should look at the value of the options granted in any given year (likely using Black-Scholes); they should not confound the board's decision process with a CEO's decision about when to monetize an option grant. In all, a study of exercised options does not speak to the purpose of the study. [As we say this, we know that an option grant itself can be a sign of self-dealing. Twenty years ago, Yermack (1997), worrying about board capture, examined how boards can give CEOs options prior to the release of good news. For the purpose 
of this commentary, we assume that boards are acting in good faith when they design CEOs' compensation contracts.]

CEO Pay vs. Residual CEO Pay. The authors did not measure CEO pay in a conventional manner. Note their description of their measure:

"Thus, following best-practice recommendations in the use of control variables (Bernerth \& Aguinis, 2016), we calculated residual scores by regressing total pay and the pay components on firm size (i.e., total assets). Henceforth, when we refer to total pay, as well as bonus, salary, and the value of options exercised, we are referring to CEO residual pay" (p. 16).

This approach is problematic for several reasons. First, controlling for a variable means removing its association not only with the dependent variable, but also with the independent variables of interest. Residualizing accomplishes the former but not the latter. As such, the authors' approach does not fully control for the variables involved (i.e., the associations between the control variables and independent variables are not taken into account). The control variables should be included as predictors in the equation that relates the independent variables to the dependent variable. Second, contrary to what the authors assert, residualizing the dependent variable on the control variables is not a "best practice." Oddly, this practice is not recommended in the article that they cite for support -- Bernerth and Aguinis (2016). We should also say that this practice deviates from the recommendations we read in the literature about how to use control variables (see for example, Atinc, Simmering and Kroll, 2011; Becker, 2005; Becker, Atinc, Breaugh, Carlson, Edwards and Spector, 2016; Breaugh, 2006; Carlson and Wu, 2012; and Spector and Brannick, 2011). Third, control variables effectively become part of the theoretical model under investigation, and should be treated as such. We see some confusion in that regard here. Consider total assets. Appearing as a variable that parses our understanding of the difference between CEO and firm performance, it is also treated as a determinant of CEO pay. Finally, the authors do not address what the portion of CEO pay that is not explained by total assets actually means. From a construct validity standpoint, the meaning and interpretation of this residualized variable should be explained.

Firm performance vs. a residual measure of CEO performance. The first point we might make here is that the literature is generally concerned about the CEO pay - firm performance link. In contrast, the authors here distinguish CEO performance from firm performance (p. 15). Before we consider their measure of CEO performance, we should note that the firm's equity holders are interested in their firm's financial performance, specifically, the market value of their equity. Alert to the principals' interest in a possible principal - agent conflict, agency theorists too are interested firm performance. That said, many scholars do wonder just how much variance in firm performance can be affected by managers' actions. Hambrick and Quigley (2014) and Quigley and Hambrick (2015), for example, join the many over the years who have tried to estimate the effect that individual leaders have on firm performance. We think one can make a case to look at both, but not to exclude a look at firm performance.

Equity holders, CEOs, directors, regulators and scholars might have a robust debate about what aspects of firm performance should be used to design a CEO's pay-for-performance contract. If the debaters conclude that we are to use something other than an omnibus accounting (e.g., ROA) or market measure (e.g., Tobin's Q) of firm performance, then we are curious to know both what aspects of firm performance are germane to that CEO contract and how to best measure those salient aspects of firm performance. Eschewing any consideration of that debate, the authors did not assess firm performance per se but moved to create a more circumscribed measure of CEO performance. And just as they did 
with CEO pay, they used a residual measure of performance as their criterion measure. As before, that decision raises a number of questions and concerns.

There are several problems with the residual scores they used here to represent their not-fullydeveloped notion of performance. Beyond skipping a considered conceptual consideration of that choice, this approach deviates from recommendations in the methodological literature concerning the use of control variables. Again, the approach fails to take into account the associations between the control variables and the independent variables included in their model. Second, the authors claim that the control variables remove the effects of "factors other than the CEO that may affect firm performance." Capital expenditures, R\&D, total assets, cash, and short-term investments comprised those control variables in their mind. That said, we doubt that these variables are, in fact, beyond the control of the CEO. Many decision-makers in the firm, including the CEO, influence these variables. For example, while a CEO works to set the firm's strategy, the firm's managers bring that strategy to life with and through their capital expenditure decisions. And of course, CEOs can direct an acquisition strategy, a strategy that has certain implications for the size of the firm's total assets (Chatterjee and Hambrick, 2007). Third, the authors control for CEO tenure, a decision that effectively removes a number of factors under the control of the CEO that can affect firm performance. Arguably, CEOs with long tenures have more experience, knowledge, and established relationships with senior executives and managers in the firm than those with shorter tenures. Tenure then is a proxy for these managerial capabilities. Fourth, the stated reason for controlling for these variables was to address "the potentially psychometrically contaminated nature of firm performance as a direct proxy for CEO contributions." As such, controlling for these variables, the residual is meant to represent a direct proxy for CEO contributions. But as we saw, the authors do not describe the nature of the performance-related factors under the control of the CEO. Instead, the authors imply that whatever is left of firm performance after removing the effects of the control variables represents a CEO's contributions. This notion does not stand to reason.

Firm performance can be influenced by all manner of factors other than those controlled by the authors. Moreover, by not explaining how CEOs contribute to firm performance, we are left with what might be termed theorization by negation -- the causes of an outcome are implied by stating what they are not, as opposed to what they are. In the present case, CEO contributions to firm performance presumably include anything other than capital expenditures, R\&D, total assets, cash, short-term investments, and CEO tenure. This style of theorizing is incomplete and leaves the myriad antecedents of firm performance to the imagination.

The implications of using residual variables to represent firm performance and CEO pay can be further understood by including the control variables, the variables they predicted and the residuals in a structural model. To illustrate, the following figure captures their model, the one that uses ROA to represent firm performance and total pay to represent CEO pay. 
Figure 1

The Aguinis, Martin, Gomez-Mejia, O'Boyle and Joo (2017) Model

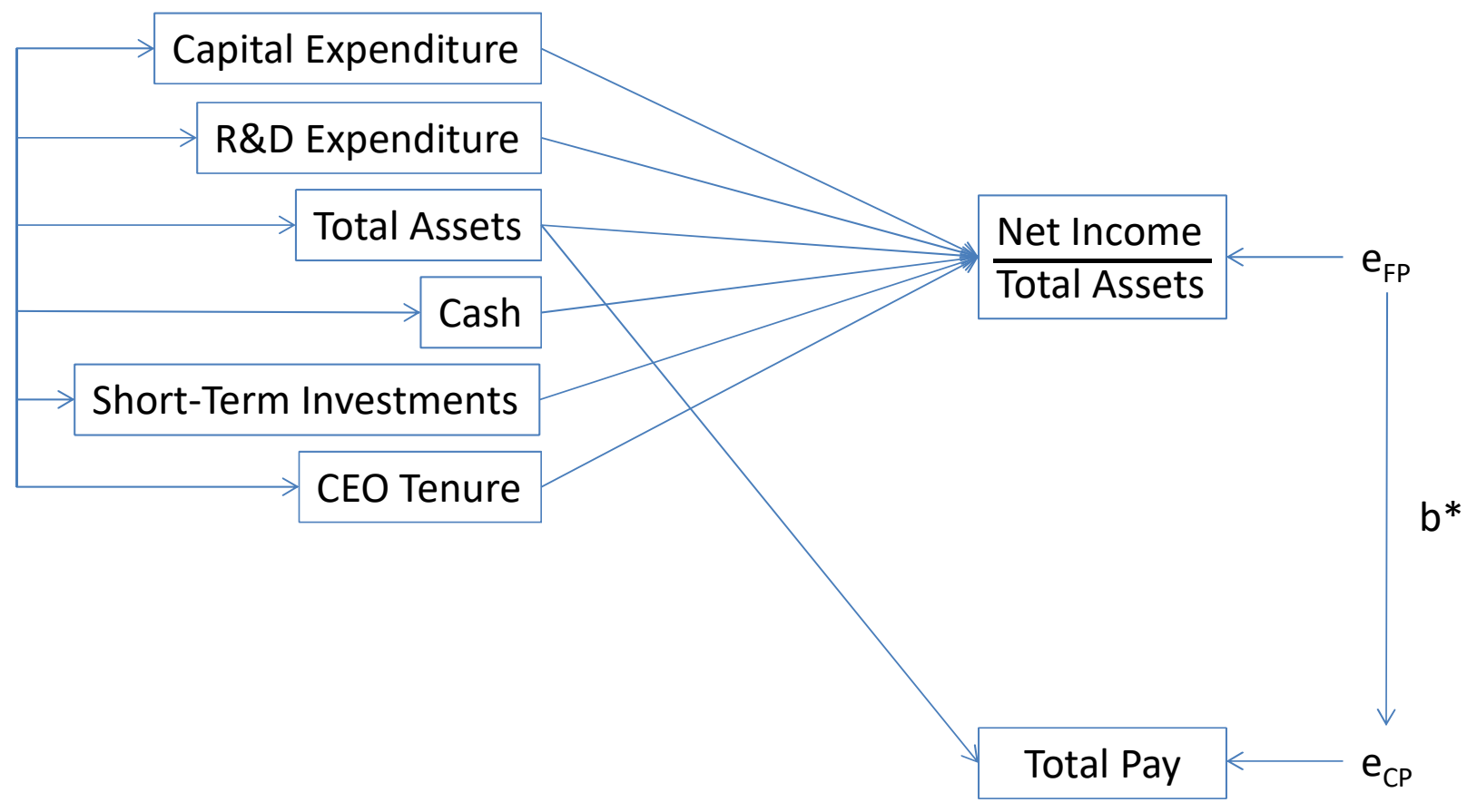

The residual for firm performance is $\mathrm{e}_{\mathrm{Fp}}$; the residual for CEO pay is $\mathrm{e}_{\mathrm{CP}}$; and $\mathrm{b}^{*}$ is the relationship between firm performance and CEO pay as estimated by Aguinis et al. (2017). This model lays bare some key issues. First, it is unclear why total assets was used as a control variable for ROA, because dividing net income by total assets to compute ROA effectively takes total assets into account. Second, looking at the effects of assets in both their measures of pay and performance puts the same variable on both sides of the equation. Third, dividing by a variable versus subtracting the effect of a variable (i.e., residualizing) are two methods for taking a variable into account. The ROA statistic, for example, takes total assets into account by dividing; residualizing ROA on the variables to its left takes total assets into account by subtracting total assets weighted by the coefficient generated by the regression equation used to derive the residual. The choice between these statistically and conceptually distinct methods should be carefully considered, explained, and justified. And fourth, the meaning of $\mathrm{e}_{\mathrm{FP}}$ and $\mathrm{e}_{\mathrm{CP}}$ is unclear. All we know is that these residuals represent those parts of ROA and CEO pay that are not explained by the control variables. The actual meaning of these parts of ROA and CEO pay is not addressed.

\section{Analytic Choices}

Once an empirical sample has been properly gathered and defined, and the constructs of interest are properly operationalized, scholars must then consider the best way to analyze their data. Looking at the authors' choices here, we came away resolved there are better ways to investigate these relationships. We will raise the questions and concerns that caught our eye and then share some ideas about how to address them. 
Consider other non-normal distributions. Aguinis et al. (2017) importantly observed that firm performance and CEO pay are unlikely to follow a normal distribution. As an alternative, they propose a power law function (a strictly negative monotonic function whose slope gradually increases but remains less than zero). This distribution is consistent with variables for which many cases have low values and progressively fewer cases have higher values, as we would expect for firm performance and CEO pay. Using the Kolmogorov-Smirnov test, the authors report that the distributions of these variables are more consistent with a power law function than they are a normal distribution. Interestingly, they never asked what kind of distribution best represents CEO pay distributions.

While the conformance of the data with a power law distribution is interesting, it would be useful to consider additional distributions. For instance, a gamma distribution can take on shapes that are similar to the power law function that the authors picture in Figure 1. It can also accommodate a wider variety of distributions, such as the exponential, Erlang and chi-square distributions. Estimating the parameters of the gamma distribution for firm performance and CEO pay would help determine whether these variables follow non-normal distributions other than the power law function.

Look at the annual CEO contacting process. The authors estimated the relationship between firm performance and an average measure of CEO pay. As we observed earlier, the relationship between these variables is likely to evolve in some kind of linked annual basis. The link might tie to the difference between pay as a reward and pay as an incentive. Let's consider how to assess pay as reward. Here, the directors responsible for determining CEO pay in a given year will take into account their firm's recent performance. This relationship could be estimated in a variety of ways. For example, scholars could use a univariate approach to repeated measures (e.g., Pedhazur, 1982). With this approach, the yearly data for each firm and CEO pair are stacked, yielding as many rows as the number of years observed for each pair. These arrays would then be stacked across all firms and CEOs. As a concrete example, let's assume that the CEOs in the 4,158 CEO-firm pairs studied here served an average of 10 years. The number of rows in the dataset would then be about 41,580 . We could control for the lack of independence created by repeatedly observing CEOs and firms by entering $N-1$ dummy variables, where $N$ is the number of CEO-firm pairs. Firm performance would then be entered as a predictor of CEO pay. With this approach, CEO pay could be linked to past, current, or future performance to capture different manifestations of the reward and incentive effects of compensation decisions.

Another approach is to use cross-lagged panel analysis (Kessler and Greenberg, 1981). Here, CEO pay at time $T$ could be related to firm performance across a series of time periods (e.g., $T-2, T-1, T, T+1, T+$ 2 , and other lags of interest). With this approach, the reward and incentive effects of compensation decisions could be examined and compared within the same model. Moreover, cross-lagged panel models can take into account the bidirectional relationships between firm performance and CEO pay. Such models can depict cyclically recursive relationships in which $X$ in Time 1 affects $Y$ at Time 2, which in turn affects $X$ in Time 3, and so forth (Billings and Wroten, 1978). This feature is especially suited to unraveling the causal direction of the relationship between firm performance and CEO pay.

Embrace nonparametric statistical techniques. Aguinis et al. (2017) assessed the relationship between CEO pay and firm performance by creating subgroups of the most highly paid CEOs and the top performing firms. The top $1 \%, 5 \%, 10 \%$, and $20 \%$ comprised the variable subgroups. They then assessed the overlap between the subgroups (e.g., looking at the number of CEOs in the top $1 \%$ of the pay distribution who worked for the firms in the top $1 \%$ of performance distribution). They also examined the relationship between firm performance and CEO pay using Kendall's tau coefficient, an appropriate choice for examining ordinal variables that cannot be assumed to be normally distributed. Because firm 
performance and CEO pay are not ordinal variables (i.e., both are expressed in monetary terms), the use of Kendall's tau was apparently motivated by the fact that firm performance and CEO pay were not normally distributed.

An alternative approach is to use nonparametric statistical techniques, such as the bootstrap (Efron and Tibshirani, 1993). With this approach, the relationship between firm performance and CEO pay would be estimated using a large number of bootstrap samples (e.g., 1,000 or more); the resulting coefficient estimates would be ranked to identify percentiles that correspond to a confidence interval of interest (e.g., the $2.5^{\text {th }}$ and $97.5^{\text {th }}$ for a 95-percent confidence interval). For the full sample and each bootstrap sample, the relationship between CEO pay and firm performance could be estimated using OLS regression, perhaps supplemented by higher-order terms to detect nonlinearities in the relationship. That said, the OLS standard errors would be disregarded in favor of percentile-based bootstrap confidence intervals as described here, which make no distributional assumptions.

Compare and contrast. Whenever we conduct research that concludes, "people do it this way but we really should do it that way," it is incumbent upon us to show the reader the results from both approaches. We highlight a few of the authors' words at the beginning and end of their paper to illustrate how they positioned their work.

"By using a power law conceptualization of the CEO pay distribution, we are able to examine differences in pay across CEOs as they actually exist. Our results provide evidence that these differences are much larger than previously thought, thus offering novel insights about theories addressing the CEO pay deservingness question" (p. 5).

"Moreover, our results point to the need to shift practitioner-thinking towards the power law view. Headhunting firms that adopt the power law view, rather than a normal distribution mindset, will be able to more accurately identify CEOs who are not the highest earners but are among the top performers" (p. 32).

Unfortunately, the authors did not analyze their data "the old way" to show us how their "new way" yields such large differences and more accurate assessments. Future work should show both sets of analyses. Readers need to see the differences for themselves. And as they show their readers these differences, they should be sure to share the descriptive statistics for all of their variables, the scatterplots that define the pay and performance distributions, and any other analyses they conduct (in this case, we did not see the regressions that produced the residuals). Transparency does matter.

\section{Concluding Words}

We began our remarks by saying that we take no joy in criticizing our distinguished colleagues' work. Indeed, it pains us to point out the limitations of this research effort. We really do hope that our comments prove to be helpful to our five colleagues and to anyone else who decides to investigate payfor-performance relationships in the C-suite and/or the nature of CEO overpayment and underpayment. Those latter quests in particular, will certainly require a deeper look at what goes on in the boardroom (Bebchuk and Fried, 2004), as well as a look at the firm's internal and external labor markets.

All of that said, we may never find close links between pay and performance. Graham, Harvey and Puri (2017) recently reminded us that there is more to the compensation story than writing efficient contracts and engineering efficient labor markets. They found a link between the perceived competence 
of CEOs and their compensation. In this case, competence was assessed by observer ratings of the CEOs' photographed faces! Jim March's (1984: 60-61) observations about the subject at hand may hold more truth than we ever imagined:

"Post-Reformation Western society tends to exalt reason and rational action. Because it is closely associated with reason, intelligence, virtue and humanity, decision making is a form of sacred activity, surrounded by rituals and beliefs that seem as ideologically central to modern culture as religious rituals, beliefs, and symbols were to pre-industrial society (Feldman and March, 1981).... From this point of view, compensation schemes are made conditional upon organizational outcomes not because we believe that individual managers can affect those outcomes significantly, but because they should be imagined to be able to do so. ... the structure and rationalization of executive compensation are sacred rituals of a world in which a sense of human control over human destiny and a belief in the importance of leadership are fundamental articles of faith."

\section{References}

Atinc, G., Simmering, M. J. and Kroll, M. J. 2011. Control variable use and reporting in macro and micro management research. Organizational Research Methods, 15, 57-74.

Bebchuk, L. A., Fried, J. M. 2004. Pay without Performance: The Unfulfilled Promise of Executive Compensation. Harvard University School Press: Cambridge, MA.

Becker, T. E. 2005. Potential problems in the statistical control of variables in organizational research: A qualitative analysis with recommendations. Organizational Research Methods, 8, 274-289.

Becker, T. E., Atinc, G., Breaugh, J. A., Carlson, K. D., Edwards, J. R. and Spector, P. E. 2016. Statistical control in correlational studies: Ten essential recommendations for organizational researchers. Journal of Organizational Behavior, 37, 157-167.

Bernerth, J. B. and Aguinis, H. 2016. A critical review and best-practice recommendations for control variable usage. Personnel Psychology, 69: 229-283.

Billings, R. S. and Wroten, S. P. 1978. Use of path analysis in industrial/organizational psychology: Criticisms and suggestions. Journal of Applied Psychology, 63, 677-688.

Breaugh, J. A. 2006. Rethinking the control of nuisance variables in theory testing. Journal of Business and Psychology, 20, 429-443.

Brockman, P., Martin, X. and Puckett, A. 2010. Voluntary disclosures and the exercise of CEO stock options. Journal of Corporate Finance, 16 (1): 120-136.

Buffett, W, 2003. To the Shareholders of Berkshire Hathaway Inc. February 21: http://www.berkshirehathaway.com/letters/2002pdf.pdf

Bureau of Labor Statistics 2017. Median weekly earnings were $\$ 849$ in the fourth quarter of 2016. The Economics Daily: https://www.bls.gov/opub/ted/2017/median-weekly-earnings-were-849-in-the-fourthquarter-of-2016.htm 
Carlson, K. D. and Wu, J. 2012. The illusion of statistical control: Control variable practice in management research. Organizational Research Methods, 15, 415-435.

Chatterjee, A., Hambrick, D.C. 2007. It's all about me: Narcissistic chief executive officers and their effects on company strategy and performance. Administrative Science Quarterly, 52: 351-386.

Chiaramonte, P. 2017. AFL-CIO 'Paywatch' report slams CEO pay but not the high pay of its own execs. May 12: http://www.foxnews.com/us/2017/05/12/afl-cio-paywatch-report-slams-ceo-pay-but-not-highpay-its-own-execs.html

Cruz, M., Foster, J.F and Schellekens, P. 2015. Ending extreme poverty and sharing prosperity: Progress and polices. Policy Research Note. World Bank Group: http://pubdocs.worldbank.org/en/109701443800596288/PRN030ct2015TwinGoals.pdf

Dun and Bradstreet. 2017. Our data: http://www.dnb.com/about-us/our-data.html

Efron, B. and Tibshirani, R. 1993. An Introduction to the Bootstrap. New York: Chapman \& Hall.

Executive Paywatch. 2017. AFL-CIO: https://aflcio.org/paywatch

Feldman, M.S. and March, J.G. 1981. Information in organizations as signal and symbol. Administrative Science Quarterly, 26 (2): 171-186.

Financial Accounting Standards Board. 2004. FASB issues final statement on accounting for share-based payment. December 16: http://www.fasb.org/news/nr121604 ebc.shtml

Goldstein, M 2017. As C.E.O. pay packages grow, top executives have the president's ear. May 26: https://www.nytimes.com/2017/05/26/business/ceo-compensation-pay-president-donald-trump.html

Graham, J.R., Harvey, C.R. and Puri, M. 2017. A corporate beauty contest. Management Science, 63(9): 3044-3056.

Hambrick, D.C. and Quigley, T. J. 2014. Toward more accurate contextualization of the CEO on firm performance. Strategic Management Journal, 35(4): 473-491.

Hardoon, D. 2017. An economy for the 99\% (OXFAM Briefing Paper). Oxfam GB, Oxford, United Kingdom.

Jensen, M. C. and Meckling, W. H. 1976. Theory of the firm: Managerial behavior, agency costs and ownership structure. Journal of Financial Economics, 3, 305-360.

Ke, B., Huddart, S. and Petroni, K. 2003. What insiders know about future earnings and how they use it: Evidence from insider trades. Journal of Accounting and Economics, 35(3): 315-346.

Kessler, R. C. and Greenberg, D. F. 1981. Linear Panel Analysis: Models of Quantitative Change. New York: Academic Press. 
Lazear, E. P. and Rosen, S. 1981. Rank-order tournaments as optimum labor contracts. Journal of Political Economy, 89: 841-865.

March, J.G. 1984. Notes on ambiguity and executive compensation. Scandinavian Journal of Management Studies, 1(1); 53-64.

Pedhazur, E. J. 1982. Multiple Regression in Behavioral Research (2nd ed.). New York: Holt.

Piketty, T. 2014. Capital in the $21^{\text {st }}$ Century. Cambridge, MA: Harvard University Press.

Pozen, R.C and Kothari, R.C. 2017. Decoding CEO pay. Harvard Business Review, 95(4): 78-84.

Quigley, T. J. and Hambrick, D.C. 2015. Has the 'CEO Effect' increased in recent decades? A new explanation for the great rise in America's attention to corporate leaders. Strategic Management Journal, 36: 821-830.

Radhakrishnan, G., Horn, J. and Milbourn, T. 2017. Comp target that work: How to keep executives fom gaming the system. Harvard Business Review, 95(5): 102-107.

Rosen, S. 1986. Prizes and incentives in elimination tournaments. American Economic Review, 76: 701715.

Spector, P. E. and Brannick, M. T. 2011. Methodological urban legends: The misuse of statistical control variables. Organizational Research Methods, 14, 287-305.

van Essen, M., Otten, J. and Carberry, E.J. 2015. Assessing managerial power theory: A meta-analytic approach to understanding the determinants of CEO compensation. Journal of Management, 41(1): 164202.

World Bank. 2017. Listed domestic companies, total: https://data.worldbank.org/indicator/CM.MKT.LDOM.NO

Yermack, D., 1997. Good timing: CEO stock option awards and company news announcements. Journal of Finance, 52, 449-476. 